Journal of MMIJ Vol.124 p.865-870(2008)

C2008 The Mining and Materials Processing Institute of Japan

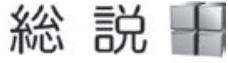

Review
次世代型石炭高効率発電のための アドバンストコールクリーニング技術の動向 *

\title{
Recent Developments in Advanced Coal Cleaning
}

by Mayumi ITO ${ }^{\mathrm{a}}$

a. Laboratory of Mineral Processing and Resources Recycling, Graduate School of Engineering, Hokkaido University, Kita 13 Nishi 8, Kita-ku, Sapporo 060-8628, Japan

(Corresponding author E-mail: itomayu@eng.hokudai.ac.jp)

The rise in demand for coal due to growth in Asia is inducing coal price increases and it will be necessary to develop cleaning method for difficult-to-treat coal. High-efficiency power generation techniques are required to reduce greenhouse gas emissions and it is necessary to reduce ash content of coal significantly before combustion. Advanced coal cleaning techniques can generate low ash coals and this paper reviews recent applications of low ash coal, recent developments in commercial scale and lab scale flotation, and research results of enhanced gravity separators and comminution.

KEY WORDS: Coal, Coal Cleaning, Flotation, Enhanced Gravity Separators

1.はじめに

石油価格の急騰により，主要なエネルギー資源である石炭に世 界的な関心が集まっている。しかし石炭利用は環境問題も抱えて おり，環境に調和したクリーンな利用が望まれる。

アジアでは急激な経済発展に伴い石炭の需要が急激に増大，価 格も上昇しており，今後は選炭が難しい石炭も開発・利用せざる をえなくなる。また, 利用に際しては地球温暖化対策のため, $\mathrm{CO}_{2}$ 排出を抑制しながら利用する「発電の高効率化」が求められ ており，一部の技術では燃焼前の選炭工程での低灰化を必要とす る。このような背景から, 従来法よりも高度な選炭技術の導入の 必要性が高まっており, 近年は実用化を意識し, 少ない投入エネ ルギー・試薬による効率的な処理法の開発を目的とした研究が増 えてきている。例えばディーゼル代替となるスラリー状燃料 (CWM or CWS) の製造前処理として, 従来とは異なる発想の効率 的な処理法が提案されている。本総説ではアドバンストコールク リーニング (高度選炭) 技術に焦点を当て，2000 年以降の論文を 中心に最近の研究開発動向を紹介寸る。

$$
\text { 2. コールクリーニング }
$$

コールクリーニング ( 選炭・脱灰 ) とは，灰分 (鉱物質含有量) の低い精炭を得るための処理を指す。採掘された原炭 (ROM 炭)

$* 2008$ 年 6 月 16 日受付 9 月 2 日受理

1. 普通会員 博士 (工学) 北海道大学 大学院工学研究科 環境循環シス テム専攻 資源再生工学研究室 助教

[ 著者連絡先 ] FAX: 011-706-6315

E-mail: itomayu@eng.hokudai.ac.jp

キーワード : 石炭, 選炭, コールクリーニング, アドバンストコールクリー ニング, 浮選, EGS

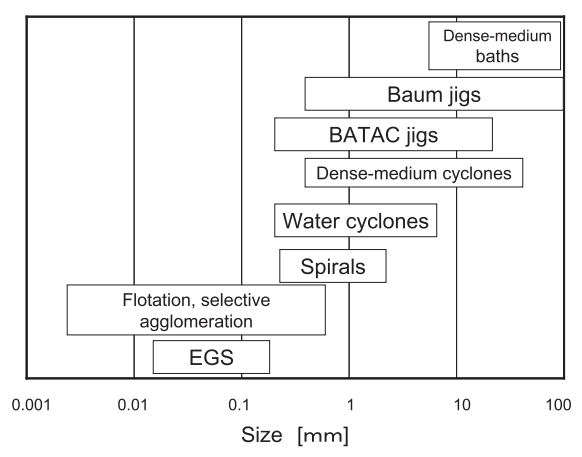

Fig.1 Particle sizes for coal cleaning methods.

を粉砕・整粒し，石炭質と鉱物質の物理的性質の差を利用して選 別することで, 石炭の灰分值が低減する。Fig. 1 に主な選炭法と それに適したフィード粒径を示す ${ }^{1)}$ 。鉱物質が比較的大きい場合 は数十〜数 $\mathrm{mm}$ 程度に破砕し, 重液バスやジグ, サイクロンなど で処理することで目標灰分值を満たす精炭を得ることが出来る。

$$
\text { 3. アドバンストコールクリーニング }
$$

ジグやサイクロンによる粗粒子の選炭では目標が達成できない 場合がある。これは1）超低灰分化，2）高硫黄炭の高度脱硫，3） 鉱物質の単体分離が困難な石炭 (選炭困難炭) の処理, 4) 微粉の 処理を目的とする場合で, より高度な選別装置で処理するためア ドバンストコールクリーニングと呼ばれる。物理的選別を行うた めには石炭質と鉱物質を粉砕工程で単体分離させる必要がある。 単体分離性は粒度の減少に伴い増大寸るため, アドバンストコー ルクリーニングでは微粒子の処理を対象とすることが多い。遠心 


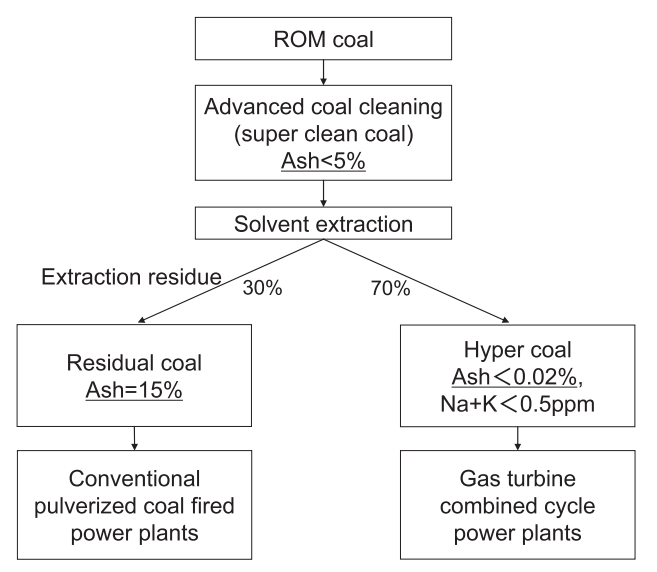

Fig.2 High efficiency power generation using hyper coal.

力を利用する比重選別装置 (EGS: Enhanced gravity separators) を用 いる方法や濡れ性の差を利用する浮選・選択凝集・造粒などの手 法がある。

酸性雨の原因である硫黄分の除去 (脱硫) の研究は, 1980 年〜 1990 年代にアメリカ炭や中国炭を対象に盛んに行なわれ, 筆者 もこの課題に取り組んだ。上述のアドバンストコールクリーニン グ技術が研究・開発されたほか, 物理選別が適用できない有機硫 黄に対し, 化学的コールクリーニング法 ${ }^{2)}$ や微生物脱硫法 ${ }^{3)}$ な どが研究された。近年は，この時期に開発された脱硫技術を改良 し, 選炭困難炭など各種の石炭に適用して, より安価に処理でき るようになりつつある。

\section{4. 高効率発電のためのアドバンストコールクリーニング}

石炭は埋蔵量が豊富で発熱量当りの価格が他のエネルギ一資源 に比べて安価であるが, 環境面では問題を抱えている。硫黄は高 価な脱硫設備を設置できない発電所では酸性雨の原因となり, 大 量の石炭を使用した後に残る灰はその処分が問題となっている。 そして, 最大の問題が地球温暖化に寄与寸る二酸化炭素の排出で ある。発電に占める石炭火力の比率 ${ }^{4)}$ はアメリカ $50 \%$, 中国 $78 \%$, ドイツ $50 \%$, 日本 $27 \%$ (2004 年) であり, 石炭は主要なエ ネルギー源である。発電で得られる単位エネルギー当りの $\mathrm{CO}_{2}$ 排出量 ${ }^{5)}$ は石炭を 1 とすると, 石油が 0.76 , 天然ガスが 0.62 で あり (2004 年), 石炭火力における発電効率の向上は $\mathrm{CO}_{2}$ 排出抑 制に大きく寄与し, 我が国の石炭利用技術開発の長期戦略の 1 つ に位置づけられている。石炭火力発電では, 石炭が鉱物粒子を含 んでいるため燃焼ガスで直接タービンを回して発電することがで きず, 燃焼で発生する熱で水を加熱し, その蒸気でタービンを回 す。高い蒸気温度で運転できれば発電効率が向上し $\mathrm{CO}_{2}$ を削減 できるため, ボイラの技術開発も盛んにおこなわれている。とこ ろで石炭の燃焼ガスで直接タービンを回すことができれば，高い 温度と圧力の流体でのタービン駆動が可能になるため蒸気タービ ンよりも高い発電効率が得られる。石炭を用いる場合も, ガス化 発電, 超低灰・低アルカリ炭のガスタービン直接燃焼発電などの 方式により発電効率の向上が期待できる ${ }^{6)}$ 。ガスタービン直接 燃焼では，生成する灰の粒径や組成がタービンブレードへの粒子 付着やスケール生成に影響し，アルカリ金属はブレード腐食物質 であるため, 超低灰分で灰粒径が小さく, 液体燃料の要求品質で ある $\mathrm{Na}+\mathrm{K}<0.5 \mathrm{ppm}$ を満たす必要がある。Fig.2 に NEDO が開発 した超低灰・低アルカリ炭 (ハイパーコール) の製造フローを示 す 7,8$)$ 。まず， ROM 炭をアドバンストコールクリーニング処理

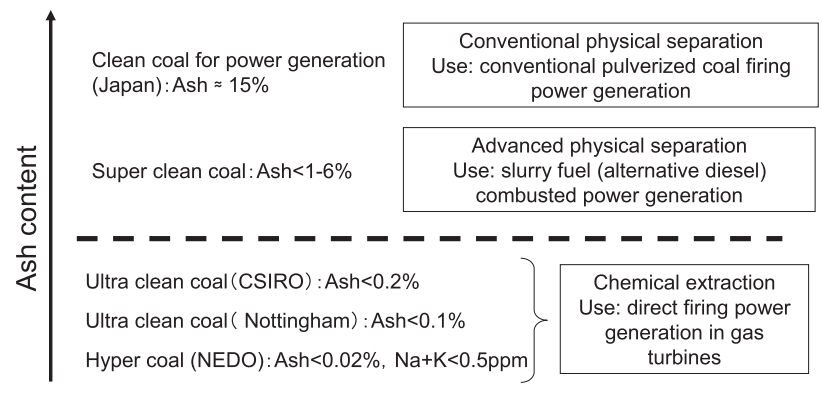

Fig.3 Ash contents of coals, production methods, and applications.

で灰分 $5 \%$ にし，次いで高温高圧下で溶剤中に溶解させる。石炭 は巨大分子が凝集した状態にあり，溶剤により非共有結合が緩和 されると液状になるため, 鉱物質は重力により沈降する。その後, 上澄溶液をイオン交換処理してアルカリ金属を除去し，溶剤を揮 発分離すると灰分 $0.02 \%$, アルカリ金属濃度 $0.5 \mathrm{ppm}$ 以下の固体 状のハイパーコールが得られる。これをガスタービンで直接燃焼 する。この技術は石炭液化で培った成果を応用しているが，石炭 液化は液体燃料として活用可能であるものの溶剂による水素添加 が必要で高コストであるのに対し，本法では水素不要で溶剂を循 環利用可能である。Fig.2 から分かるように溶剤抽出での石炭溶 解量は $70 \%$ 程度であり, 抽出残渣炭を既往の火力発電で使う場 合の目標灰分は約 $15 \%$ であるため, 処理前にアドバンストコー ルクリーニングにより灰分を $5 \%$ 程度まで低減する必要がある。 同様にガスタービン直接燃焼の目的でオーストラリア (CSIRO) や イギリス (Nottingham Fuel and Energy Centre) でもウルトラクリー ンコール (灰分 0.1-0.2\%) 製造の技術開発が行なわれている 9,10$)$ が，こちらはアルカリや酸で浸出して鉱物質除去を行う方法を採 用しており，灰分やアルカリ金属濃度がハイパーコールよりも若 干高い。

微粒の精炭 (10-20 $\mu \mathrm{m})$ を水に固体濃度 70\% 程度で添加剤とと もに分散させ，スラリー状の燃料として利用寸る (CWM or CWS) 技術も開発されている例えば 6)。この場合も灰分をおよそ1-6\% に低減する必要があり,スーパークリーンコールなどと呼ばれる。 この燃料はディーゼル代替や高効率微粉炭火力発電などで利用可 能と言われている。

Fig. 3 に石炭分分と利用用途・製造方法を示す。ガスタービン 直接燃焼に用いるためには徹底的に不純物を除去する必要があ り, 最終的に溶剂や酸を用いて化学処理され灰分 $0.2 \%$ 以下にな る。ディーゼル代替や高効率微粉炭火力発電に供することのでき るスラリー状燃料は物理選別法で製造可能で，灰分 $6 \%$ 以下程度 の低灰炭が望まれており，灰分 $1 \%$ くらいが物理選別による限界 である ${ }^{11)}$ 。

\section{5. アドバンストコールクリーニングの研究動向}

このように，石炭を高度利用するためにはアドバンストコール クリーニングが必要不可欠であり, 1980 年代から各国で研究さ れている。初期の研究は, 物理選別の限界に挑戦しどこまで低灰 分化できるかを検討するものが多く, 灰分の低いスーパークリー ンコールを作るために数 $\mu \mathrm{m}$ まで粉砕し, 浮選や造粒で処理する 方法の開発が盛んに行なわれ, 筆者の所属する研究室でも多数の 検討が行われた例えば 12)。コールクリーニングに関する総説・著 作も多数あり例えば 13), 石炭浮選を中心とした著作 ${ }^{1)}$ も出版され ている。筆者はコールクリーニング・アドバンストコールクリー ニングの研究論文を毎年収集し, 日本エネルギー学会誌に掲載さ 
- Flotation $\square$ Water cyclones \& spirals $\square$ Dense medium $\square$ Jigs $\square$ Other

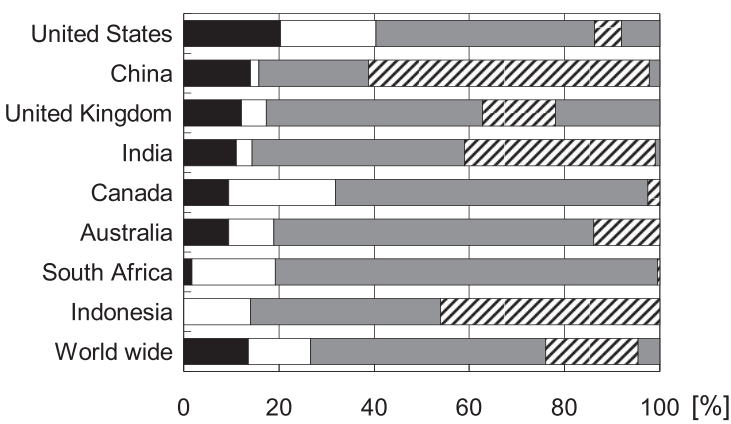

Fig.4 Installed capacity of coal preparation methods.

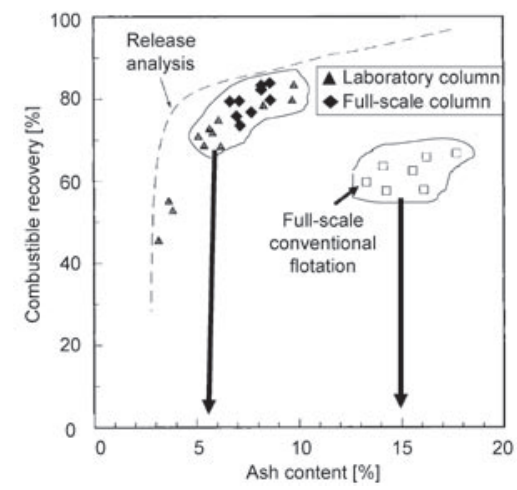

Fig.5 Performance of column and conventional flotation cells.

れるエネルギー関連の論文のレビュー「昨年度における重要なエ ネルギー関係事項 (コールクリーニング)」を担当・執筆している。 本報では，収集した論文のうちのアドバンストコールクリーニン グ関連，2000 年以降の研究を中心に研究動向を紹介寸る。

石炭生成時の混入などに起因する鉱物粒子の大きさは，1-10 $\mu \mathrm{m}$ 程度のものと $100 \mu \mathrm{m}$ 以上のものが存在し ${ }^{14)}$ ，アドバンスト コールクリーニングではこれらの鉱物が単体分離している粒径, 約 $500 \mu \mathrm{m}$ 以下 (低灰化を目指寸場合は $10 \mu \mathrm{m}$ 以下) の微粉を選別 する。

\section{$5 \cdot 1$ 浮選 · 選択凝集}

濡れ性の差を利用する浮選や選択凝集・造粒法は微粒子選別に適 しており，鉱物質に比べ石炭質の多くは疎水性が大であることか ら多くの研究がなされてきた。

$5 \cdot 1 \cdot 1$ 浮選の操業 ていたが，粗粒子の処理に比べ粉砕・分級・試薬・脱水コストが かかるため実用化していなかった。しかし装置改良が進み, 1990 年代後半から急激に導入が増大し，2000 年にはアメリカで $20.3 \%$, 中国で $14.0 \%$, 世界平均 $13.6 \%$ に達した (Fig. 4)。現在も 導入が進んでいる。導入の目的は 3 章で述べた鉱物質の単体分離 が困難な石炭 (選炭困難炭) の処理, 従来廃棄していた微粉炭の 回収が主である。浮選機は機械攪拌型とカラム型があるが石炭浮 選では Fig. 5 に示すようにカラム型の方が選別精度が高く, リ リースアナリシス法による処理結果 (紛れ込みを極力抑える条件 で浮選し, 対象とする石炭を極めて高い選別効率で浮選分離した 場合に得られる灰分值を知るための試験法）に非常に近い。カラ ム型は機械攪拌型よりも微細気泡を発生させることができ, 選別 ゾーンでの選別性も高いため微粒子を対象に高効率分離が達成で きる。Table 1 はアメリカの主な石炭商用カラム浮選機の一覧で
Table 1 Commercial column installations for coal in the U.S.

\begin{tabular}{|c|c|c|c|c|c|}
\hline Company/Location & Brand & $\begin{array}{l}\text { Number } \\
\text { of Units }\end{array}$ & $\begin{array}{c}\text { Diameter, } \\
t\end{array}$ & $\begin{array}{c}\text { Hoight, } \\
\text { it }\end{array}$ & Particle Size \\
\hline Alpha Natural Resources - White Tail & Eriez/CPT & 5 & 14 & 28 & 100 mesh $\times 0$ \\
\hline Alpha Natural Resources-Middle Fork & Microcel & 5 & 10 & 25 & 100 mesh $\times 0$ \\
\hline Alpha Natural Resources - Holston & Microcel & 1 & 14 & 30 & 100 mesh $\times 0$ \\
\hline Alpha Natural Resources - Roxanna & Microcel & 2 & 13 & 28 & 65 mesh $\times 0$ \\
\hline Alpha Natural Resources - Torns Creek & Microcel & 2 & 14 & 28 & 100 mesh $\times 0$ \\
\hline Alpha Natural Resources - Brooks Run & Microcel & 2 & 15 & 35 & 100 mesh $\times 0$ \\
\hline Carbontronics Fuel-Pawney & Jameson & 1 & 16 & 12 & 100 mesh $\times 0$ \\
\hline Carbontronics Fuel-Gibraltar & Jameson & 1 & 16 & 12 & 100 mesh $\times 0$ \\
\hline Carbontronics Fuel-Linville & Jameson & 1 & 16 & 12 & 100 mesh $\times 0$ \\
\hline Cline Resources - Coal Clean & Eriez/CPT & 3 & 15 & 28 & 100 mesh $\times 0$ \\
\hline CONSOL Energy-Keystone & Jameson & 1 & 16 & 12 & 100 mesh $\times 0$ \\
\hline $\mathrm{CQ}$, Inc.-Ginger Hill & Jameson & 1 & 16 & 12 & 100 mesh $\times 0$ \\
\hline CQ, Inc.-Pleasant Ridge & Jameson & 1 & 16 & 12 & 100 mesh $\times 0$ \\
\hline International Coal Group-Marrowbone & Microcel & 1 & 8 & 26 & 150 mesh $\times 0$ \\
\hline Horizon Natural Resources-Lady Dunn & Microcel & 3 & 14 & 30 & $100 \mathrm{mesh} \times 0$ \\
\hline Massey Energy-Power Mountain & Eriez/CPT & 2 & 13 & 24 & $100 \times 325$ mesh \\
\hline Massey Energy-Liberty & Eriez/CPT & 3 & 13 & 24 & $100 \times 325$ mesh \\
\hline Massey Energy - Bandmill & Eimoo & 2 & 13 & 24 & $100 \times 325$ mesh \\
\hline Massey Energy-Marfork & Jameson & 4 & 16 & 12 & 100 mesh $\times 0$ \\
\hline Ohio Valley-Century & Eriez/CPT & 2 & 14 & 24 & $100 \times 325$ mesh \\
\hline Peabody-Sugar Camp & Jameson & 1 & 16 & 12 & 100 mesh $\times 0$ \\
\hline Powell Mountain - Mayflower & Ken-Flote & 4 & 8 & 22 & $100 \mathrm{mesh} \times 0$ \\
\hline Sigmon Mining -Sigmon & Eriez/CPT & 2 & 14 & 28 & 100 mesh $\times 0$ \\
\hline TECO Mining - Clintwood Elkhorn & Eriez/CPT & 2 & 10 & 24 & $100 \times 325$ mesh \\
\hline
\end{tabular}

ある。Microcel, Jameson, CoalPro (Eriez/CPT) が主に使われてお り，一般に $150 \mu \mathrm{m}$ 以下の粒群に適用されている。

Microcel カラム浮選機はフィード部のモーションレスミキサー で微細気泡と粒子を効率的に付着させることが出来るため, 1980 〜 1990 年代にスーパークリーンコール製造の研究に用いられた。 モーションレスミキサーを設置したカラム浮選機では, 少ない捕 収剂添加量で低灰炭が得られることが実証されている ${ }^{16)}$ 。従来 の Jameson 浮選機は Microcel のように選別効率が高くはないが, コンパクトな設備で安い運転コストという利点がある。その後改 良が進み 2001 年には米国東部の選炭工場に直径 $5 \mathrm{~m}(0.8 \mathrm{t} / \mathrm{h})$ の Jamson 浮選機が導入され ${ }^{17)} ， 90 \%$ 網下通過径 $45 \mu \mathrm{m}$, 灰分 $30 \%$ のフィードから灰分 $6 \%$ の低灰炭が得られたことが報告された。 また, 通常のカラム浮選機では $-150 \mu \mathrm{m}$ 程度の微粒子を処理する が, Cowburn ら 18) は, Jameson 浮選機での石炭粒子の回収率が 粒子径の増大と共に低下寸る要因についてまとめ, 粗粒子 $(+0.5 \mathrm{~mm})$ の浮遊性を向上させるためには, 攪挥強度を低減する ためにジェット速度を小さくするのが有効であることを報告し た。オーストラリアのプラントにその成果が導入されており, こ の方法で粗粒を含む幅広い粒度分布を持つフィードを処理でき る。その他, 浮選機を導入した結果, 著しい脱灰効果が得られた という報告や, 炭種の特性に応じた最適処理条件の検討などが多 く報告されている。

石炭浮選において粒子, 捕収剂, 気泡間の相互作用は極めて複 雑である。捕収剂として油を用いるが, 油添加は石炭表面を疎水 化するとともに，粒子の非選択的な凝集ももたらす。この現象は 炭質によってその生じ方が異なる。Polata ら ${ }^{19)}$ は, 粒子, 捕収剂, 気泡間の相互作用を化学的, 物理的 (機械的) 作用に分類し, 既 往の文献を調べて整理し, 現場の技術者に役立つように, 総説と してまとめている。

$5 \cdot 1 \cdot 2$ 浮選・選択凝集に関する研究 超微粒子の処理 では, 粒子の比表面積が大きく多量に試薬を要する, 粗粒に比べ 気泡付着が困難, 紛れ込みが多いなど問題があるため, これらの 克服を目指した研究が近年多く行われている。

Honaker ら ${ }^{20)}$ は，フロスゾーンで気泡が合一する際に疎水性 粒子よりも弱疎水性粒子が脱離する確率が高くなり選別性が向上 する現象を利用して, フロス層に強疎水性粒子を添加する方法を 提案した。これを利用し, 無煙炭の浮選に踈水性の強い瀝青炭粒 子を添加することで，回収率を低下させずに灰分を $5 \%$ 低減でき た。Atesok ${ }^{21)}$ は, $-38 \mu \mathrm{m}$ の微粉炭にキャリアーとして0.1-0.3mm 


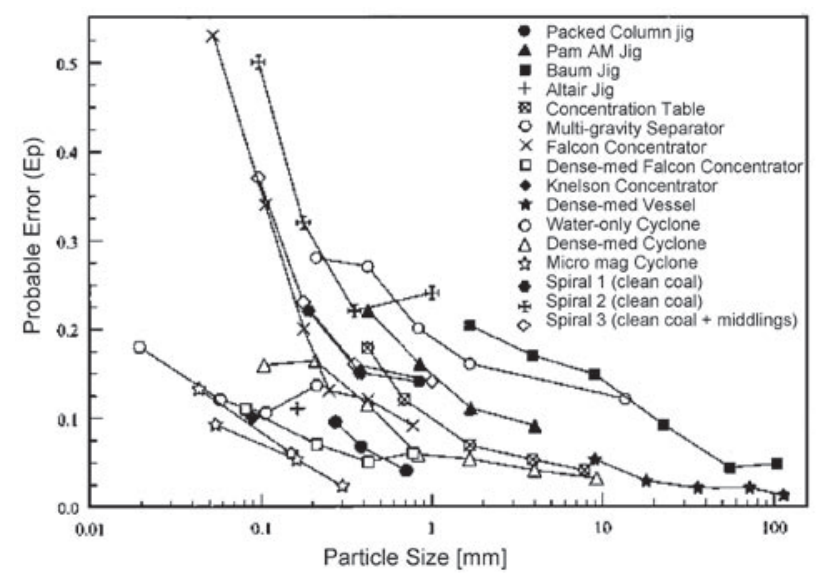

Fig.6-1 Probable error as a function of particle size.

の疎水性石炭を添加し, 微粉炭をキャリアー粒子に付着・凝集さ せた状態で起泡剤のみで浮選すると，灰分を $16.3 \%$ から $8.3 \%$ に 低減できることを報告した。Shen ら ${ }^{22)}$ は, 平均粒径 4-5 $\mu \mathrm{m}$ の 石炭スラリーにイソオクタンを加え, いったん加圧下においた後, 減圧し, 攪拌することで微細気泡 - 石炭凝集体を形成させ, これ を浮上させて精炭を回収する方法を検討し，2段処理で灰分を $33 \%$ から $6.3 \%$ に低減できることを報告した。Honaker ら ${ }^{23)}$ は, 捕収剤などの薬剤を添加しなくても 3-5 $\mu \mathrm{m}$ の微粒石炭の脱灰が できる可能性を見出した。捕収剂無添加で $\mathrm{pH}$ のみを変化させた 溶液中で石炭微粒子を凝集沈降させ, 鉱物微粒子が分散している 上澄と分離し, 脱灰率を求めた。7炭種の選択凝集試験を行った ところ, ほとんどの石炭は, pH8.5-9.5 で脱灰効果が認められた。 ゼータ電位測定，接触角測定結果より，pH8.5-9.5 の範囲で鉱物 質が分散し, 石炭質が凝集するため, 灰分及び硫黄分除去率が高 くなること, 接触角の大きな疎水性石炭では疎水性相互作用力に よる凝集力が大きく寄与することを明らかにした。また, DLVO 理論を拡大して疎水性相互作用力を付加した式を用いて粒子間に 働く全相互作用ポテンシャルを求め, 疎水性凝集による脱灰が起 こることを示した。 $-10 \mu \mathrm{m}$ の Elikhorn No.3 炭では, 可然成分回 収率 $86.3 \%$ で, 灰分が $12 \%$ から $1.14 \%$ に低下, 黄鉄鉱硫黄分が $0.25 \%$ から $0.03 \%$ に低下した。微粒子浮選では微細気泡を用いる ため, 気泡の上昇速度が遅いことが問題となる。Ping ら 24) は微 細気泡と遠心力を用いる円形遠心浮選機を開発し, 微細気泡によ る微粒石炭の浮選においても短時間で高い選別性が得られること を報告した。湯川ら ${ }^{25)}$ は, 低品位炭を熱水乾燥法で処理して表 面を疎水性に改質してから浮選し, その精炭をアルカリ熱水溶液 法で処理することで, 灰分 $1 \%$ 以下の低灰炭が得られることを報 告した。褐炭などの低品位炭は発熱量が低く, 高含水率で自然発 火しや寸いなどの理由により山元での利用を除きほとんどが未利 用である。膨大な賦存量のある低品位炭の改質と低灰分化を行な い, スラリー燃料化して輸送し高効率発電で利用するための研究 が活発化している。

$5 \cdot 1 \cdot 3$ スラリー燃料製造のための逆浮選＼cjkstart従来の選炭 では, 粉砕産物を粗粒, 細粒, 微粒に分級後, それぞれに適した 選炭法で処理し, 脱水を経て出荷している。しかし粗粒では単体 分離性が悪いため選別成績に限界があり, 微粒は脱水・乾燥にコ ストを要する。微粉炭を水に懸濁した状態 (スラリー状態) で発 電に利用する方式を採用すれば，山元で微粉砕して全量を浮選す ることで低灰分にでき，また選炭後にスラリー化を行なうため脱 水が不要となる。スラリー化に際しては, 石炭の水中での安定分

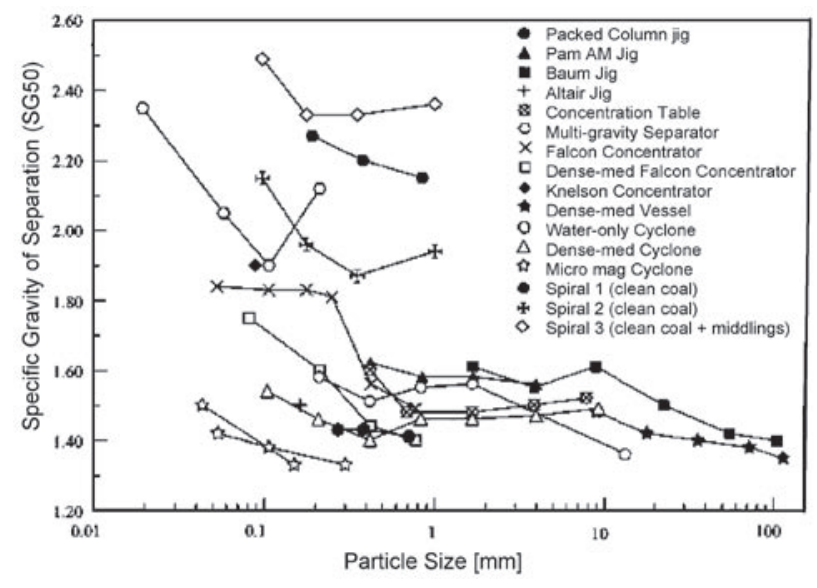

Fig.6-2 Specific gravity of separation as a function of particle size.

散のために石炭粒子の親水化が必要であり，選炭産物が親水性で あれば, 安定化試薬の削減につながる。表面酸化した石炭や低品 位炭は疎水性が低いことから Laskowski ら ${ }^{11)}$ は, 鉱物質を浮かせ, 石炭を尾鉱として回収する逆浮選が有効であることを指摘し，逆 浮選のための捕収剂であるアミン系 DTAC, DTAB の効果 ${ }^{26)}$ 検討した。さらにアミン系の捕収剂は鉱物表面に付着して疎水化 するが気液界面に移動しやすくロスが生じるため, エアロゾルと して送気ガスと共に浮選機に導入する方法 (The zero conditioning time method) ${ }^{27)}$ により試薬量を大幅に削減できることを報告して いる。

\section{$5 \cdot 2$ 遠心力を利用する比重選別装置 (EGS)}

石炭と鉱物質の疎水性の差が小さい場合は比重差を利用する選 別の方が良い成績が得られる。超微粒子の浮選や造粒に比べて選 別精度がおちるため低灰炭の製造には向かないが, 既存の火力発 電向けの微粒子処理に適用できる。遠心力を利用寸る装置は, 流 動層型 (Knelson concentrator)，薄層選別型 (Falcon concentrator, Multi-Gravity separator) , ジグ型 (Kelsey jig, Altair jig, Packed column jig) などがあり, 1980 年代から開発され始め, 当初は脱硫のために 比重の重い黄鉄鉱 ( 比重 5) の除去に焦点を当てて研究されていた が, その後 25-150 $\mu \mathrm{m}$ 粒群で著しい脱灰効果もあることが見出され, 一部の装置では分離比重 1.5 を達成できることも分かってきた 28-30)。各装置の原理については筆者らの総説に記述がある ${ }^{31) 。 ~}$

平島ら ${ }^{32)}$ は釧路コールマインの選炭廃水を処理しているシッ クナー水に可燃成分が含まれていることに着目し, サイクロン分 級により微粒子をカットした後に, Multi-Gravity separator で処理 することで，可然成分を $57 \%$ 回収でき，灰分を $43 \%$ から $18 \%$ に 低減できたことを報告した。Honaker ${ }^{33)} ら は ，-150 \mu \mathrm{m}$ の石炭を Knelson concentrator 一導入する際に, 浮選で用いる起泡剂を添加 し，スタティックミキサーを用いて微粒気泡を発生させて処理す る方法を考案した。気泡は疎水性である石炭粒子に付着し, みか けの比重が小さくなるため, 親水性で比重の大きな粒子との分離 性が向上し, 石炭回収率が 10-20\% 増大した。Falcon concentrator では通常, 水で処理するが, 重液をもちいることで歩留まりを $20 \%$ 上昇できたことを Honaker ら ${ }^{34)}$ は報告している。 Mohanty ら ${ }^{35)}$ は, 44-600 $\mu \mathrm{m}$ 粒群を Altair ジグで処理し, 分離比重 1.55, テラ指数 (Probable error) 0.09 を達成できたことを報告している。 Peng ら ${ }^{36)}$ は, 150-1000 $\mu \mathrm{m}$ 粒群を Packed column ジグで処理し, 灰分 35-50\% が 5-6\%に低減できたことを報告している。さらに 彼らは様々な選別装置で報告されているテラ指数 (Probable error, Ep) や分離比重と粒径の関係を図にまとめ (Fig. 6) 比較した。石 
炭は産地によって単体分離性・分離のし易さが異なるため比較が 難しいが，細粒群の場合も低い分離比重で精度良く分離できるよ うになってきたことがこの図から分かる。

\section{$5 \cdot 3$ その他の研究}

粉砕に消費されるエネルギーはアメリカの発電量の $1.5 \%$ を占め, 鉱物処理プロセスの $60-70 \%$ を占めていると推定されており，粉 砕の高効率化は重要である。 Ozbayoglu $5^{37)}$ は，マイクロウェー ブ粉砕前処理による石炭の粉砕性向上効果について, 粒径や照射 パワー・時間を変化させた試験を行い，その有効性を報告した。 褐炭にマイクロウェーブを照射すると水分含有量の低下とともに 黄鉄鉱の磁性を増大させることができるため, マイクロウェーブ 処理後に粉砕し, 磁選や静電選別で処理する方法も提案されてい る ${ }^{38,39)}$ 。Cui ら 40) は, 高圧ウォータージェットミルの適用を検 討し, 粗粒子をフィードに戻寸機構やメンテナンスの容易な装置 に改良することで，石炭粉砕に利用可能であることを報告した。 選炭における粉砕では整粒に加え, 粒子の単体分離が重要である。 Ito ら ${ }^{41)}$ は, 石炭質/鉱物境界を選択的に破壊する電気パルス 法の選炭への適用と, そのメカニズムの解明に取り組んでおり, 石炭および人工試料の粉砕特性について報告した。

オーストラリアでは, 従来スパイラル選別機で処理していた石炭 を, 複数の平行傾斜板を持つ流動層選別機 (Reflux Classifier：RC) で処理する方式に切り替える傾向にある ${ }^{42)}$ 。この装置では，水 中沈降速度の速い粒子は傾斜板上に沈積して下方に滑り落ち, 沈 降速度の遅い粒子は水流と共にオーバーフローし分離される。 Galvin らは, 400t/h〜 600t/h の処理量を持つ実機の RCで $0.25-2 \mathrm{~mm}$ の石炭を処理し, 既存の選別装置より選炭性が良いこと,パイロッ トスケール試験と同等の選別性が得られたことを報告している。 Honaker ${ }^{43)}$ らは, スパイラル分級機で $44 \mu \mathrm{m}$ の微粒子も処理可能 であることを示し，そのための運転条件を検討した。

インドの然料炭の 9 割は灰分約 $40 \%$ の F グレードに分類され るので 44)，インド政府は 2002 年以降ピットから $1000 \mathrm{~km}$ 以上遠 隔又は都市域の発電所で使用寸る石炭について規制 (灰分く 34\%)しており，8 割近くの発電所が該当するため, インド炭の コールクリーニングに関する論文も多い。Dwari ${ }^{44)}$ は, 乾式のソー ティング・比重・磁気・静電選別法について装置や原理をレビュー し，インド炭の選炭結果についてまとめた。

インドのコークス用炭の選炭工場では, 約 2 割を浮選で処理し ている。Dey ${ }^{45)}$ は, 粒群別のコレクターレス浮選において, 産地 や粒度によって最適な起泡剂の種類が異なることを報告した。ま た微粉 $(-0.5 \mathrm{~mm})$ を分級し, 粗粒をコレクターレス浮選, 微粒を 多段浮選し，それぞれ得た産物をブレンドしてコークス用や発電 用として全量利用する方法を提案した ${ }^{46)}$ 。Banerjee ${ }^{47)}$ は, イン ドのコークス用炭の浮選において, $+0.5 \mathrm{~mm}$ 粗粒群の浮遊性を改 善するために, 初めに微粉を浮かし, その後捕収剂を追添して粗 粒を浮かせる方法を提案した。インドの Tata 製鉄グループは, アルコール・ポリグリコール・エーテル系捕収剤の起泡性・安定 性・気泡径を測定し, 動的気泡指数と臨界合一濃度には負の相関 があること 48)，インド炭の浮選結果からアルコール系の MIBC は選択性が高く微粉が浮き, ポリグリコール系の Dow froth はフ ロスの含水率が高く鉱物質の紛れ込みが起こるものの粗粒も回収 できることを報告し，混合して用いるのが効果的であることを報 告している ${ }^{49)}$ 。

アメリカでは 2007 年から, 石炭火力発電所からの水銀の排ガ ス規制が始ったため, 燃焼前 (事前) 脱水銀処理に関する研究も 多い。Guffey ら 50) は, 予備過熱による脱水銀の効果について研 究し, $250^{\circ} \mathrm{C}$ で 4 分ほど処理すると脱水銀 (60-70\%) できるが,
さらに除去するためには水銀と炭素の結合を切断する別処理が必 要になることを報告している。Dronen $5^{51)}$ は, 酸洗浄および微 生物処理による石炭からの水銀除去について検討した。強酸と弱 酸の 2 段階処理で $90 \%$ の水銀が除去可能であり, Acidithiobacillus ferrooxidans および Acidithiobacillus thiooxidansによる微生物処理 も効果的であることを報告した。微生物処理の場合，黄鉄鉱と共 存するヒ素, セレン, カドミウム, クロムなどが除去され, 酸洗 浄の場合は有機物と結合している水銀も除去されている可能性が ある。Aller ら ${ }^{52)}$ は微生物処理で微量元素のカドミウム, 七素, ホウ素が除去されることを報告している。

石炭は産地や炭層によって鉱物質の種類や含有量・粒径などが 変動し, 同一の処理を行っても選炭成績が異なるため, 現場では 浮沈試験法で選炭のしや寸さ, 選炭成績の予測・評価を行なって いる。Oki $5^{53)}$ は, 石炭の浮沈試験データから鉱物質の単体分 離性を把握するための指数算出方法を開発した。最も軽比重の粒 子の灰分 (限界灰分) と, 最も高比重の粒子の片刃率の最小值か ら, 鉱物質単体分離度の最大值 (MLmax) を算出し, 単体分離度 の評価指標とするもので，石炭の粒子径や鉱物組成などの石炭性 状はこの MLmax の值に反映されるため, 鉱物質の単体分離度の 指標として有用である。オーストラリアでは四塩化炭素などの有 害な有機溶剤を用いる標準浮沈試験法 (AS4156.1) の取り消しを 検討しており, 代替法が必要となっている。Galvin ${ }^{54)}$ はこの代替 法をレビューし, 各手法の利点・欠点をまとめた。無機比重液・ 擬重液を用いる方法や，水ひやジグの原理を利用するもの，密度 測定法, トレーサー法, CT による断層撮影法などを紹介している。

\section{6.おわりに}

コールクリーニングの研究分野では，高度脱硫や超低灰炭製造 を目的とした物理選別の限界に挑戦するような大型のプロジェク 卜研究が 1980 年から 1990 年代に世界中で盛んに行なわれ, 各種 の新技術が開発されたが，当時は良質な石炭が低価格で供給され ていたため, これらの技術は実用化には至らない次世代技術とし て位置づけられていた。しかし近年, 低質な石炭の地場利用であっ ても環境に配慮することが求められ，先進国では $\mathrm{CO}_{2}$ 排出を抑 制しながら利用する次世代型石炭高効率発電への移行が急速に進 んでおり，アドバストコールクリーニング技術の導入が脚光をあ びている。研究論文をみても, 2000 年代に入ってからは実用化 を重視した, 少ない投入エネルギー・試薬による効率的な処理法 の研究開発が多く報告され, 実プラントへの浮選機の導入などが 急ピッチで進んでいる。今後もこれらの技術はますます磨きがか けられ普及していくであろう。

逆浮選や選択粉砕, 微粒子処理手法の粗粒子への適用拡大など の技術は，従来の選炭プロセスを大きく変える必要があるが，粉 砕を含めた処理フローの大幅な見直しが可能であるため, 大きな 効果が期待できる。

山元以外での利用が難しい褐炭は, 脱灰・脱水改質・スラリー 化などの処理で遠方でも使えるようになる。経済的な選炭処理・ 燃焼利用の目途がつけば大幅な利用の拡大が見込まれる次世代技 術であり，実用化に向けた研究開発の意義は大きい。

\section{References}

1) J. S. Laskowski: Coal Flotation and Fine Coal Utilization (Elsevier, Amsterdam, 2001), p.2. 2) T. Oki: Proc. MMIJ Fall Meeting (1995), Vol. H, p.1.

3) T. Nagaoka: Journal of MMIJ, 113 (1997), 219.

4) IEA Electricity Information 2006 Edition.

5) METI: Energy Hakusyo (Gyosei, Tokyo, 2004), p.53.

6) Japan Coal Energy Center: Clean Coal Technologies in Japan (Japan Coal Energy Center, Tokyo, 2006). 
7) M. Ito et al.: Proc. MMIJ Fall Meeting (2002), Vol. CD, p.65.

8) I. Saito and S. Shinozaki: Journal of MMIJ, 118 (2002), 115

9) http://www.det.csiro.au/science/lee_cc/ultra_clean_coal.htm

10) K. M. Steel et al.: Fuel, 82 (2003), 1917.

11) J. S. Laskowski: Proc. of XXIII Int. Miner. Proc. Congr. (2006) , p.1101.

12) T. Hirajima et al.: Journal of MMIJ, 110 (1994) , 473.

13) D. G. Osborn: Coal Preparation Technology (Graham and Trotman Limited, London, 1988).

14) J. S. Laskowski: Froth flotation A century of innovation (Society for Mining, Metallurgy, and Exploration, Inc., Colorad, 2006), p.613.

15) R.Kempnich: Proc. of XX VII Inter. Coal Prep. Exhib. and Conf. (2000), p.5.

16) T. Hirajima et al.: Proc. of XI Int. Coal Prep. Congr. (1990) , p.361.

17) M. K.Mohanty: Miner. Eng., 14 (2001), 1531

18) J. Cowburn et al.: Miner. Eng., 19 (2006), 609

19) M. Polata et al.: Int. J. Miner. Process, 72 (2003) , 199

20) R. Q.Honaker et al.: Miner. Eng., 19 (2006), 687.

21) G. Atesok et al.: Miner. Eng., 14 (2001), 661.

22) M. Shen et al.: Coal Prep., 21 (2000), 277.

23) R. Q.Honaker et al.: Coal Prep., 25 (2005) , 81

24) D. Ping et al.: Proc. XIV Int. Coal Prep. Conf (2002), p.69.

25) K. Yukawa et al.: Journal of MMIJ, 118 (2002), 695.

26) K.Ding et al.: Miner. Eng., 19 (2006), 72.

27) K.Ding et al.: Miner. Eng., 19 (2006) , 79

28) G. H.Luttrell et al.: Porc. XII Int. Coal Prep. Conf. (1995), p.281

29) R. Q. Honaker et al.: Porc. XIII Int. Coal Prep. Conf. (1998), p.349.

30) R. Q. Honaker et al.: Coal Prep., 21 (2000), 211
31) M. Tsunekawa et al.: Journal of MMIJ, 121 (2005), 467.

32) T.Hirajima et al.: Journal of MMIJ, 121 (2005), 456

33) R. Q.Honaker et al.: Coal Prep., 25 (2005), 99.

34) R. Q.Honaker et al.: Miner. Eng., 13 (2000) , 415.

35) M. K.Mohanty et al.: Coal Prep., 20 (1999), 85.

36) F. F.Peng et al.: Coal Prep., 22 (2002), 199.

37) G. Ozbayoglu and T.Depci: Proc. XXIII Int. Miner. Proc. Congr. (2006) , p.1177.

38) T.Uslu et al.: Fuel Processing Technology, 85 (2004) , 21.

39) L.Tur čániová et al.: Fuel, 83 (2004), 2075.

40) L.Cui et al.: Int. J. Miner. Process., 81 (2006) , 113

41) M.Ito. et al.: Proc. XXIII Int. Miner. Proc. Congr. (2006) , p.247.

42) K. P. Galvin et al.: Miner. Eng., 18 (2005), 19

43) R. Q. Honaker et al.: Miner. Eng., 20 (2007), 1315

44) R. K. Dwari et. al.: Mineral Processing \& extractive Mettal. Rev., 28 (2007) , 177-234

45) S. Dey et al.: Int. J. Coal Prep. and Util., 27 (2007) , 4

46) S. Dey et al.: Fuel Processing Technology, 88 (2007), 585.

47) P. K. Banerjee et al.: Int. J. Coal Prep. and Util., 27 (2007), 39

48) A. K. Gupta et al.: Int. J. Coal Prep. and Util., 27 (2007), 107.

49) A. K. Gupta et al.: Int. J. Miner. Process, 82 (2007), 126

50) F. D.Guffey et al.: Fuel Processing Technology, 85 (2004), 521

51) L. C. Dronen et al.: Fuel, 83 (2004), 181.

52) A. Aller etal.: Process Metall., 9A (1999), 99.

53) T.Oki et al.: Miner. Eng., 17 (2004), 39.

54) K. P.Galvin: Coal Prep., 26 (2006), 209. 